\title{
BISNIS DAN PRAKTIK SOSIAL: AT-TAQWA BUSINESS CENTRE, PRIMKOPJAMAS DAN LAZISWA MASJID AT-TAQWACIREBON
}

\author{
Achmad Otong Busthomi \\ Fakultas Syariah dan Ekonomi Islam \\ Institut Agama Islam Negeri Syekh Nurjati Cirebon \\ email: tomibust@yahoo.com
}

\begin{abstract}
The results of business and social practice research conducted at-Taqwa Cirebon mosque, namely At-Taqwa Center management distinguish the financial results of business entities resulting from the use of land owned that is used for contracts or transactions that intentionally to get profit or profit, With finances generated from infaq, shadaqah and other tabarru akad, although from both financial models will be collected and reported to the main treasurer. The At-Taqwa Center social practice is activities or programs undertaken that are socially not expecting profit.
\end{abstract}

Keywords: Busines, Social, Namely At-Taqwa Center.

\begin{abstract}
Abstrak
Hasil dari penelitian praktik bisnis dan sosial yang dilakukan masjid at-Taqwa Cirebon, yaitu manajemen At-Taqwa Centre membedakan keuangan yang dihasilkan dari badan usaha yang dihasilkan dari pemanfaatan lahan yang dimiliki yang digunakan untuk akad-akad atau transaksi yang sengaja untuk mendapatkan laba atau profit, dengan keuangan yang dihasilkan dari infak, shadaqah dan akad-akad tabarru lainnya, meskipun dari kedua model keuangan ini nantinya dikumpulkan dan dilaporkan pada bendahara utama. Praktik sosial At-Taqwa Centre adalah kegiatan-kegiatan atau program-program yang dilakukan yang bersifat sosial tidak mengharapkan keuntungan.
\end{abstract}

Kata Kunci: Bisnis, Sosial, Manajemen At-Taqwa Centre. 


\section{PENDAHULUAN}

Masjid dalam sejarah Islam merupakan sarana utama dalam pengembangan ajaran Islam. Masjid bukan hanya sekedar sebagai tempat peribadatan saja, tapi lebih dari itu masjid bisa sebagai tempat pertemuan silaturahmi, sebagai forum diskusi, bahkan sebagai tempat pengadilan. Nabi Muhammad Saw beserta para penggantinya (Khulafaur Rasidin) sebagai pemimpin umat sekaligus sebagai imam masjid pada saat itu, merupakan pablic figure (pemimpin dan panutan) dan juga mempunyai komitment yang sangat kuat untuk dapat mensejahterakan masyarakat.

Ketika Rasulullah SAW. membangun masjid, baik untuk yang pertama di Quba' maupun di Madinah, tidak hanya dimaksudkan untuk sarana beribadah kepada Allah SWT. semata. Lebih dari itu masjid juga digunakan sebagai sarana mencerdaskan umat, sebagai sarana berkomunikasi antara umat dan sekaligus sebagai pusat kegiatan umat secara positif dan produktif.

Dalam rangka untuk melestarikan dan mengembangkan masjid, kiranya diperlukan pemikiran dan gagasan inovatif dan sekaligus kemauan semua fihak terutama para pengelolanya. Mengelola masjid pada zaman sekarang ini memerlukan ilmu dan ketrampilan manajemen. Pengurus masjid (Takmir) harus mampu menyesuaikan diri dengan perubahan zaman.

Di bawah sistem pengelolaan masjid yang tradisional, umat Islam akan sangat sulit berkembang. Bukannya tambah maju, mereka malahan akan tercecer dan makin jauh tertinggal oleh perputaran zaman. Masjid niscaya akan berada pada posisi yang stagnan, yang pada akhirnya bisa ditinggal oleh jamaahnya.

Menurut Muhamad Taslim ${ }^{1}$ setidaknya ada 3 (tiga) bidang pembinaan yang harus dilaksanakan, yaitu:

\footnotetext{
${ }^{1}$ http://ririgusriani.blogspot.co.id/2013/06/m anajemen-pengelolaan-masjid-idarah.html. Diakses pada tanggal 14 April 2016.
}

\section{Pembinaan Bidang Idarah (Manajemen)}

Pembinaan Bidang Idarah ini dimaksudkan untuk meningkatkan kualitas pengorganisasian kepengurusan masjid dan pengadministrasian yang rapi, trasparan dan juga mendorong partisipasi jama'ah agar tidak ada pemyalah gunaan wewenang oleh pengurus masjid.

Secara garis besarnya yang terpenting dalam manajemen masjid adalah Idarah binail maady (Physical management) yaitu manajemen secara fisik yang meliputi kepengurusan, peraturan, kehormatan, keamanan, tata tertib, keuangan dan lainya, yang kedua adalah Idarah binail ruhy (functional management) yaitu pengaturan tentang pelaksanaan fungsi masjid sebagai wadah pembinaan umat, akhlakul karimah, pendidikan Islam, pusat kebudayaan dan lainnya. Oleh karena itu dalam menyusun kepengurusan sangatlah penting agar program kerja dan penjabarannya menjadi jelas. Disamping manajemen kepengurusan ada juga manajemen kesektariatan, manajemen keuangan, manajemen dana dan usaha, manajemen pembinaan jamaah, manajemen pendidikan dan pelatihan.

\section{Pembinaan Bidang Imarah (Memamurkan Masjid) \\ Pembinaan Bidang Imarah ini menjadi kewajiban setiap muslim yang mengharapkan untuk memperoleh bimbingan dan petunjuk dari Allah Swt. dalam surat At-Taubah ayat 18 disebutkan:}

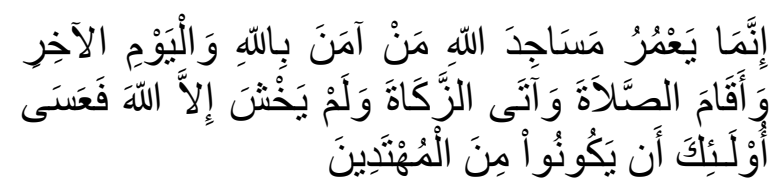

Arttinya: Hanya yang memakmurkan masjid-masjid Allah ialah orangorang yang beriman kepada Allah dan hari kemudian, serta tetap mendirikan shalat, menunaikan zakat, dan tidak takut kepada siapapun selain kepada Allah maka merekalah orang-orang yang mendapat petunjuk. ${ }^{2}$

${ }^{2}$ QS. At-Taubah (9): 18. 


\section{Pembinaan Bidang Riayah (Pemeliharaan Masjid)}

Pembinaan Bidang Riayah ini untuk pembangunan fisik, keamanan, kenyamanan dan kebersihan. Sebagaimana yang diisyaratkan oleh Allah Swt dalam surat Ali 'Imran ayat 97:

Artinya: ...Barang siapa memasuki Baitullah menjadi amanlah dia. ${ }^{3}$

Masjid ibarat ladang yang amat luas yang siap untuk digarap dengan ber-bagai aktivitas kegiatan, ia juga seperti sarang lebah yang tidak boleh kosong dari orang yang rukuk, sujud, berdzikir kepada Allah, membaca Al-Qur'an, belajar dan mengajarkan ilmu. Imam masjid memiliki posisi yang tinggi ditengah-tengah masyarakat, ucapannya banyak didengar serta pendapatnya cenderung untuk diterima. Bagaimana seorang imam tidak memiliki posisi ini sedangkan masyarakat telah menjadikannya pemimpin dalam menjalankan syiar yang amat besar dari syiar-syiar Islam yaitu shalat

Shalat berjamaah secara religi mempunyai keistimewaan tersendiri, yaitu dengan dilipatgandakannya pahala 27 derajat lebih tinggi dari pada shalat sendiri bahkan diiwajibkannya shalat berjamaah (kemudian ahli fiqh menjadikan shalat berjamaah sebagai sunnah muakkad), mempunyai korelasi yang sangat signifikan bagi kontrol sosial masyarakat. Dapat dibayangkan untuk mengumpulkan masyarakat dalam acara tertentu memerlukan cost yang tidak sedikit, tapi umat Islam dengan kesadaran penuh ia bisa berkumpul silaturahim dengan saudaranya lima kali sehari bahkan satu minggu sekali dalam skala yang lebih besar dilakukan pada shalat jum'at.

Masjid merupakan aset bangsa yang dapat digunakan untuk memberdayakan ekonomi kerakyatan berbasis masjid.Dapat dibayangkan kalau setiap masjid memiliki

${ }^{3}$ QS. Ali 'Imran (3): 97. aset yang besar dan aset tersebut dapat dioptimalkan maka insya Allah dapat mengentaskan kemiskinan di negara ini yang nota bene faktor kemiskinan itulah yang menjadi dasar timbulnya efek-efek negatif yang terjadi dimasyarakat.

Kekayaan Takmir Masjid diperoleh dari usaha-usaha dan sumbangan yang halal dan tidak mengikat. Dana terkumpul merupakan amanah yang harus dipertanggungjawabkan penggunaannya, karena itu perlu dikelola dengan baik. Adanya Pedoman Pengelolaan Keuangan dimaksudkan agar dapat memberi acuan kepada Pengurus dalam mengelola dana organisasi tersebut. Pedoman Pengelolaan Keuangan Takmir Masjid mengatur keuangan organisasi yang meliputi sumber dana, penganggaran kegiatan maupun lalu lintas keuangannya. Uang yang masuk dan keluar harus halal, jelas sumbernya, tercatat dengan rapi dan dilaporkan secara periodik. Demikian pula prosedur pemasukan dan pengeluaran dana harus ditata dan dilaksanakan dengan baik.

Sumber Dana yang didapatkan masjid bisa jadi beraneka ragam sumbernya, seperti pertama, donatur Tetap, yaitu sumbangan dari jama'ah atau pihak lain yang secara periodic memberikan infak. Kedua, donator Tidak Tetap, yaitu sumbangan dari berbagai pihak yang dilakukan dengan mengajukan permohonan, misalnya kepada instansi pemerintah, instansi swasta, lembaga donor atau simpatisan. Ketiga, donator Bebas, yaitu sumbangan yang diperoleh dari lingkungan jama'ah sendiri atau pihak luar yang bersifat insidentil. Hal ini dengan menyediakan kotak mal maupun penggalangan dana dari masyarakat. Dan keempat, usaha Ekonomi, yaitu dana yang diperoleh dengan melakukan aktivitas ekonomi khususnya dibidang jasa dan perdagangan.

Dalam menjalankan roda kepengurusannya, DKM At-Taqwa Kota Cirebon tentunya memakai praktik-praktik yang Islami. Khususnya dalam pengelolaan manajemen idarah, imarah dan riayah. Akad dilihat dari segi tujuannya dapat 
dibagi menjadi dua bagian yaitu akad tabarru' dan akad tijarah. ${ }^{4}$ Adapun menurut Oni Sahroni dan Adiwarman A. Karim bahwa untuk mencapai tujuan distribusi (tadawul) Islam mensyariatkan akad bisnis (Mu'awadah) dan akad social (Tabarru') demikian juga yang diutarakan oleh Selamet Wiyono. Akad tabarru' adalah akad yang tujuannya semata-mata untuk kebaikan atau kebajikan, tolong menolong, dan tidak untuk mencari keuntungan, contoh dari akad ini adalah hibah, wakaf, hadiah dan pinjam meminjam (qard). Akad tijarah atau mu'awadah (Bisnis) adalah akad yang tujuannya untuk mencari keuntungan (kelebihan), contoh dari akad ini adalah akad jual beli, sewa menyewa, kerja sama (mudharabah dan musyarakah).

Dalam bentuk keseharian akad tabarru' atau sosial (Grotuotus Contrack) terjadi dalam tiga bentuk, yaitu pertama, meminjamkan uang, yaitu qard (pinjaman yang diberikan tanpa mensyaratkan apapun, selain pengembalian pinjaman), rahn (pinjaman yang mensyaratkan suatu jaminan dalam bentuk atau jumlah tertentu), hiwalah (pinjaman dengan cara mengambil alih piutang dari pihak lain). Kedua, meminjamkan Jasa, yaitu wakalah (pinjaman berupa kemampuan kita saat ini untuk melakukan sesuatu atas nama orang lain), wadi'ah (pemeliharaan dan penitipan selama pemberian jasa tersebut, hampir mirip wakalah), kafalah. Dan ketiga, memberikan sesuatu, seperti wakaf, hibah dan shadaqah.

Sedangkan akad tijarah atau mu'awadah (bisnis) atau (compensational contrack) adalah untuk mencari keuntungan menyangkut perjanjian transaksi untuk laba (for profit transactiaon), seperti investasi, jual beli, sewa menyewa. Akad tijarah inipun dibagi menjadi dua kelompok, yaitu

${ }^{4}$ Neneng Nurhasanah, Mudharabah dalam Teori dan Praktik (Bandung: PT. Refika Aditama, 2015), 42.

${ }^{5}$ Oni Sahroni dan Adiwarman A. Karim, Maqashid Bisnis dan Keuangan Islam Sintesis Fikih dan Ekonomi (Jakarta: PT. Raja Grafindo Persada, 2015), 72. pertama, Natural Uncertainty Contract (NUC) yaitu kontrak transaksi yang secara alamiah mengandung ketidakpastian dalam memperoleh keuntungan, seperti musyarakah, mudharabah, muzara'ah, musaqah, dan mukhabarah. Dan kedua, Natural Certainty Contract (NCC) yaitu kontrak transaksi dalam bisnis yang memiliki kepastian keuntungan dan pendapatannya, baik dari segi jumlah dan waktu penyerahannya, seperti murabahah, salam dan ijarah.

Konsep keuangan syariah yang diterapkan pada awalnya adalah konsep Baitul Maal wat Tamwil (BMT) yang lahir pada tahun 1984. Pada dasarnya Maal, berarti harta yang diperoleh dari ZIS (zakat, infak, shadaqah) khusus untuk pengamanan pembiayaan 8 (delpan) asnaf atau golongan yang berhak menerima zakat. Dan Tamwil adalah murni bisnis dengan hitungan dan akad yang jelas, yang mengandung artian kewajiban dan hak-haknya digunakan secara bisnis murni.

BMT merupakan salah satu badan keuangan syariah yang banyak beredar dimasyarakat kita, bahkan ada sebagian umat Islam menggantinya dengan istilah yang lebih dengan kelompoknya. Meskipun demikian pemerintah menggunakan istilahistilah tersebut ke dalam Koperasi Jasa Keuangan Syariah (KJKS), yang nantinya akan diawasi oleh OJK (Otoritas Jasa Keuangan) bagian pengawasan industry keuangan non bank.

Dari sini muncul pertanyaan, apakah bentuk-bentuk kerjasama antara DKM Attaqwa dengan pihak lain baik yang merupakan praktik bisnis ataupun sosial sudah sesuai dengan aturan ekonomi syariah atau sebaliknya? Demikian juga legalitas badan usaha yang dimiliki baik bisnis ataupun sosialnya. Bagaimana kontribusi akad bisnis dan sosial dalam meningkatkan jiwa kewirausahaan masyarakat dan pemberdayaannya adalah keterkaitan dan suatu keharusan yang akan menjadi tanggung jawab kita semua?

Berdasarkan latar belakang dan pembatasan masalah di atas, maka 
penelitian ini dapat dirumuskan dalam pertanyaan-pertanyaan sebagai berikut, yaitu pertama, bagaimana praktik bisnis di masjid At Taqwa Kota Cirebon? Kedua, bagaimana praktik sosial di masjid At Taqwa Kota Cirebon? Dan ketiga, bagaimana dampak praktik bisnis dan sosial di masjid At-Taqwa Kota Cirebon bagi kewirausaan dan pemberdayaan masyarakat.

\section{METODE PENELITIAN}

Pendekatan penelitian yang digunakan adalah metode penelitian kualitatif deskriptif, yaitu prosedur penelitian yang menghasilkan data deskriptif berupa rumusan tertulis atau lisan dari orang-orang dan perilaku yang dapat diamati. ${ }^{6}$ Adapun metode kualitatif digunakan untuk mengumpulkan data dari para informan terpilih dengan instrumen panduan pertanyaan yang telah disiapkan sebelumnya.

Karakteristik dari penelitian ini akan lebih mudah apabila berhadapan dengan kenyataan dan menyajikan secara langsung. Hakikat hubungan antara peneliti dengan responden, lebih peka dan lebih menyesuaikan diri dengan penajaman pengarang bersama terhadap pola-pola nilai yang dihadapi. ${ }^{7}$

\section{Sumber Data Penelitian}

Sumber data yang digunakan dalam penelitian kali ini, yaitu pertama, data primer yang diperoleh data secara langsung dengan melakukan wawancara terhadap pihak-pihak terkait, seperti ketua umum AtTaqwa Center, Ketua At-Taqwa Bisnis Centre, Ketua Primkopjamas, direktur Laziswa. Kedua, data sekunder yaitu data yang diperoleh dengan membaca literatur kepustakaan, media cetak atau elektronik, dan brosur yang ada hubungannya dengan penelitian yang akan dilakukan. Data ini

${ }^{6}$ Lexy J. Moleong. Metodologi Penelitian Kualitatif (Bandung: PT. Remaja Rosda Karya, 1997), 3.

${ }^{7}$ Nasution. S, Metode Penelitian Naturalistik, Kualitatif (Bandung: Tarsito, 2005), 18. digunakan oleh peneliti sebagai pelengkap dari data primer.

\section{Tekhnik Pengumpulan Data: Metode Observasi}

Observasi adalah alat pengumpulan data yang dilakukan dengan cara mengamati dan mencatat secara sistemik gejala-gejala yang diselidiki. ${ }^{8}$ Observasi juga sebagai salah satu cara pengamatan yang dilakukan dengan cara melakukan pengamatan terhadap objek yang akan diteliti. Dalam hal ini peneliti menggunakan observasi non partisipan, yaitu hanya melihat dan mendengarkan pada situasi tertentu tanpa partisipasi aktif didalamnya, ${ }^{9}$ Atau lebih dikenal dengan sebutan observasi partisiatif pasif. $^{10}$

Observasi ini dilakukan untuk memperoleh data dari informasi melalui keadaan yang sebenarnya, yang dalam hal ini peneliti mengamati paraktik bisnis dan sosial yang ada di masjid At-Taqwa, sekaligus dampaknya terhadap kewirausahaan dan pemberdayaan masyarakat.

\section{Tekhnik Pengumpulan Data: Metode Wawancara}

Wawancara adalah proses tanya jawab dalam penelitian yang berlangsung secara lisan dimana dua orang atau lebih bertatap muka, mendengarkan secara langsung informasi-informasi atau keteranganketerangan lebih lanjut. ${ }^{11}$

Melalui wawancara atau interview kali ini, peneliti bermaksud untuk mengetahui sejarah, prosedur, dan pengelolaan AtTaqwa centre, khususnya mengenai program bisnis dan sosial yang di At-Taqwa centre. Perlengkapan yang digunakan untuk

${ }^{8}$ Cholid Narbuko dan Abu Ahmadi, Metodologi Penelitian (Jakarta: Bumi Aksara, 2007), 70.

${ }^{9}$ Emzir, Metodologi Penelitian Kualitatif: Analisis Data (Jakarta: Rajawali Press, 2012), 40.

${ }^{10}$ Sugiono, Memahami Penelitian Kualitatif (Bandung: Alfabeta, 2014), 62.

${ }^{11}$ Cholid Narbuko dan Abu Ahmadi, Metodologi Penelitian, 83. 
kegiatan wawancara ini, seperti daftar pertanyaan, buku catatan, alat untuk mendokumentasikan, recorder, dan sebagainya.

\section{PERANAN MASJID AT-TAQWA}

Masjid At-Taqwa Kota Cirebon didirikan pada tahun 1918 di suatu kampung yang bernama Kejaksan, yang terdiri dari dua bagian, yang satu untuk dipergunakan sebagai Tajug Agung (sekarang berganti nama Masjid At-Taqwa) dan setengah bagian yang lain dipergunakan sebagai alunalun. Pada tahun ini juga Jalan RA. Kartini merupakan Jalan Kereta Api menuju ke Pelabuhan Cirebon yang kemudian dipindahkan ke Jalan KS. Tubun.

Nama masjid At-Taqwa Cirebon, semula bernama Tajug Agung yang bangunannya sudah cukup lama dan tua, serta ruangannya terlalu kecil dan letaknya kurang menghadap kiblat. Melihat keadaan seperti ini, R.M. Arhatha yang pada waktu itu menjabat sebagai kepala Koordinator Urusan Agama Cirebon mempunyai gagasan untuk merenovasi Tajug Agung tersebut di tempat yang lama dengan mengambil nama masjid At-Taqwa, karena sudah ada masjid agung yang terletak di kasepuhan yang sekarang menjadi masjid Agung Sang Cipta Rasa. Seolah-olah pada waktu itu tidak dibenarkan dua nama yang sama pada dua masjid yang letaknya masih dalam satu kota, yaitu Tajug Agung dan masjid Agung. Akhirnya pada tahun 1951 terwujudlah bangunan masjid tersebut dan diresmikan menjadi masjid At-Taqwa tahun 1963.

Gaya arsitektur masjid dengan mencirikan bangunan tropis dengan atap jurai serta dilengkapi dengan empat menara kecil dan sebuah menara setinggi 65 meter. Namun, kehadiran gerbang (gate) selebar 3 meter sebelum memasuki bangunan utama yang menjadi point of interest bangunan masjid memberi nilai tersendiri. ${ }^{12}$

\footnotetext{
${ }^{12}$ https://id.wikipedia.org/wiki/Masjid_AtTaqwa_Cirebon. Diakses pada tanggal 10 April 2016.
}

Masjid At-Taqwa sekarang telah menjadi icon kota Cirebon. Banyak orang berkunjumg ke masjid tersebut dengan berbagai macam tujuan, ada yang hanya sekedar mampir untuk menunaikan shalat fardu sambil melepas lelah, ada yang mengahadiri acara perkawinan ataupun diskusi, ada yang mengantar anak sekolah di TPQ dan TPA. Kemudian ada pula yang datang untuk menghadiri pengajian rutin, dan sebagainya.

Langkah yang sangat cepat dan signifikan yang dilakukan oleh para pengurus masjid At-Taqwa, menunjukan keberhasilan manajemen pengelolaan masjid yang menyangkut idarah, imarah dan riayah. Idarah, pengelolaan masjid diatur dalam sebuah organisasi dan administrasi yang baik Imarah, berarti pengelolaan masjid yang berkaitan dengan mengembangkan dan memberdayakan masjid sebagai pusat kegiatan ibadah, seperti kegiatan ibadah (solat lima waktu, solat Jumat, solat Id), majelis taklim, pembinaan remaja masjid, penerbitan bulletin dan pengelolaan perpustakaan. Selanjutnya, Riayah berkaitan dengan pemeliharaan, menjaga dan mengembangkan fisik dan fasilitas masjid, termasuk menjaga keamanan dan kenyamanan masjid.

Penggalian dana dan pemanfaatan peluang bisnis yang dilakukan oleh pengurus masjid At-Taqwa tidak terlepas dari kepekaan mereka dalam memahami akad tijarah atau mu'awadah dan akad tabarru'. Penggunaaan dana sosial berupa ziswa (zakat, infak, sadaqah dan wakaf) menjadi modal bisnis merupakan hal yang tabu bagi masyarakat awam. Namun, hal ini menjadi hal yang perlu diklarifikasi dan diperdebatkan dengan adanya perkembangan ekonomi modern dan lahirnya lembaga-lembaga syariah yang berkompeten dalam melahirkan fatwa-fatwa tentang ekonomi syariah.

Legalitas keuangan masjid At-Taqwa kota Cirebon tentunya harus mengacu pada ketentuan-ketentuan yang berlaku yang ditetapkan oleh badan-badan keauangan 
syariah yang ada di Indonesia, atau bentuk kerjasama dengan lembaga keuangan syariah lainnya.

Kekayaan takmir masjid diperoleh dari usaha-usaha dan sumbangan yang halal dan tidak mengikat. Dana yang terkumpul merupakan amanah yang harus dipertanggungjawabkan penggunaannya, sehingga perlu dikelola dengan baik. Oleh karena itu pedoman pengelolaan keuangan yang ada, dimaksudkan dapat menjadi acuan kepada Pengurus dalam mengelola dana organisasi tersebut. Pedoman pengelolaan keuangan takmir masjid, mengatur keuangan organisasi yang meliputi sumber dana, penganggaran kegiatan maupun lalu lintas keuangannya. Uang yang masuk dan keluar harus halal, jelas sumbernya, tercatat dengan rapi dan dilaporkan secara periodik. Demikian pula prosedur pemasukan dan pengeluaran dana harus ditata dan dilaksanakan dengan baik.

\section{AT-TAQWA BUSINESS CENTER (ABC)}

Masjid At-Taqwa kota Cirebon pada awalnya mempunyai dua bentuk organisasi, yaitu Dewan Kemakmuran Masjid (DKM) dan Islamic Centre Kota Cirebon (ICC). Terbentuknya DKM tentunya mempunyai tujuan yang sama dengan DKM yang ada di masjid-masjid lainnya. Tujuan yang dimaksud, yaitu untuk memakmurkan masjid sebagai sarana peribadatan juga sebagai sarana kegiatan-kegiatan lain yang bersifat mahdhah dan ghairu mahdhah, seperti tempat kajian ilmu keagamaan, tempat kepanitiaan zakat, infak, sedekah, wakaf, kurban dan tempat kegiatan-kegiatan keislaman lainnya, baik dilaksanakan oleh DKM sendiri atau pihak lain yang ingin menggunakannya untuk keperluan syiar Islam.

Islamic Centre At-Taqwa sebenarnya adalah sebuah lembaga yang mengurusi tentang kajian keislaman, dakwah dan pendidikan. Islamic Centre adalah lembaga keagamaan yang dalam fungsinya sebagai pusat pembinaan dan pengembangan agama Islam, yang berperan sebagai mimbar
Pelaksanaan Dakwah dalam Era Pembangunan (Dirjen Binmas Islam Kementerian Agama RI tahun 2004). Namun, menurut Sidi Gazalba Islamic Centre adalah wadah bagi aktivitas-aktivitas kemasyarakatan yang berdasarkan Islam. Baik Islam sebagai agama maupun Islam dalam pengertian sebagai pegangan hidup (way of life). Dengan demikian, dapat disimpulkan bahwa aktivitas-aktivitas di dalamnya mencakup nilai-nilai peribadatan yang sekaligus nilai-nilai kemasyarakatan.

Pada tahun 2013 ketika H. Ahmad Yani terpilih menjadi ketua umum DKM At-Taqwa yang kemudian berubah menjadi At-Taqwa Centre untuk masa khidmat 2013 / 2018, beliau berinisiatif untuk menggabungkan antara management DKM Raya At-Taqwa kota Cirebon dengan Islamic Centre Cirebon (ICC) menjadi satu atap, yaitu satu management yang bernama At-Taqwa Centre. Hal tersebut sesuai dengan Anggaran Dasar pasal 2 ayat 1 yang berbunyi "Organisasi At-Taqwa Centre Kota Cirebon dibentuk berdasarkan Surat Keputusan Walikota Cirebon Nomor: 451.1/Kep.46-Adm Kesra/2011 tentang: Penetapan Pengurus Dewan Kemakmuran masjid raya At Taqwa dan Islamic Centre kota Cirebon", dan pasal 2 ayat 2 bahwa "Organisasi At-Taqwa Centre Kota Cirebon merupakan gabungan dua lembaga yakni Masjid Raya At-Taqwa dan Islamic Centre Kota Cirebon".

At-Taqwa Business Centre (ABC) ada di bawah naungan Kepala Bidang Ekonomi dan Kerjasama. Dengan demikian, dapat ditegaskan bahwa At-Taqwa Business Centre bukan termasuk UKM (Unit Kegiatan Masjid), tapi lebih mengarah pada program penggalian dana selain dari Zakat, Infak, Sedekah dan Wakaf (ziswaf).

\section{PRIMKOPJAMAS (Primer Koperasi Jamaah Masjid)}

Praktik sosial sebagaimana telah dituangkan pada pembahasan di atas merupakan transaksi yang tidak mengharapkan profit. Primkopjamas adalah sejnis koperasi yang 
hanya diperuntukan bagi pengurus dan anggota UKM At-Taqwa Centre.

Primkopjamas At-Taqwa ini sudah berbadan hukum, dengan SK Kepala BPN No. 3.X.A.2005 tanggal 5 Nopember 2005, sehingga memiliki anggota dan kegiatan yang jelas. Anggota Primkopjamas kurang lebih 100 orang, ${ }^{13}$ yang terdiri dari karyawan dan anggota UKM. Adapun iuran wajib anggota koperasi tidaklah sama, untuk karyawan iuran wajib sebesar Rp 50.000,(lima puluh ribu rupiah), sedangkan iuran wajib sebesar Rp 25.000,- (dua puluh lima ribu rupiah) ditambah dengan tabungan sukarela yang besarnya tidak ditentukan.

Kemudian, untuk kegiatan Primkopjamas At-Taqwa Centre dapat dikelompokan dalam 3 (tiga) pokok kegiatan, yaitu pertama, kegiatan Koperasi Masjid berupa TOSERBA (Toko Serba Ada), yang diperuntukan untuk jamaah masjid dan masyarakat yang singgah disana. Koperasi ini menjual barang-barang yang dibutuhkan untuk operasional At-Taqwa Centre, seperti kain lap, sandal, spidol, photo copy dan sebagainya. Harapannya adalah apabila anggota ataupun kepentingan organisasi baik pengurus ataupun UKM memerlukan sesuatu tidak harus keluar untuk berbelanja. Kedua, menghimpun dana hibah untuk kesejahteraan anggota. Dan ketiga, menerima pesanan hewan qurban.

\section{LAZISWA (Lembaga Zakat, Infak, Sedekah dan Wakaf)}

Pengelolaan zakat di Indonesia memang banyak mengalami perkembangan yang signifikan, hal ini dapat dilihat banyaknya regulasi peraturan dan perundang-ungangan tentang panitia yang berkecimpunga dalam pengumpulan zakat. Zakat memang merupakan suatu kewajiban bagi setiap warga negara yang beragama Islam, disamping zakat fitrah, ada juga zakat perniagaan, zakat Maal.

${ }^{13}$ Wawancara dengan Bapak Fikri pada tanggal 21 Nopember 2016, beliau berasal dari Banten dan sebagai petugas Koperasi Masjid.
Pada awal Laziswa At-Taqwa masih berbentuk UPZ (Unit Pengelola Zakat) hal ini sesuai dengan UU tentang pengelolaan zakat tahun 1998. Disamping mengelola zakat UPZ At-Taqwa ini juga menangani infak dan shadaqah.

Pada tanggal 04 Mei tahun 2006, UPZ At-Taqwa ini resmi berbadan hukum dengan nama Laziswa At-Taqwa (Lembaga Amil Zakat, Infak, Shodaqoh dan Wakaf), dengan akta notaris Lia Amalia, Sh No. 05/2006.

Kepercayaan masyarakat untuk membayar zakat, infak, shodaqoh dan wakaf melalui Laziswa At-Taqwa mengali peningkatan yang signifikan. Pada tahun 2002 mencapai 30 Juta, 2003 mencapai 36 juta, 2004 mencapai 52 juta, 3005 mencapai 80 juta, dan pada tahun 2012 mencapat 465.616.717. dengan perincian muzakki zakat fitrah 3.002 orang, 119 muzakki zakat maal, 948 orang infak shodaqoh, 23 orang fidyah dan 27 orang wakaf produktif. ${ }^{14}$

\section{DAMPAK PRAKTIK BISNIS DAN SOSIAL MASJID AT-TAQWA CIREBON}

At-Taqwa Centre yang menerapkan sistem keuangan satu atap, dalam kiprahnya menjadi semakin lebih baik. Baik dalam pegelolaan sarana dan prasarana ibadah, maupun kerjasama dengan pihak luar, yang kesemuanya mengarah pada terciptanya keharmonisan antara hubungan dengan sesama manusia dan hubungan manusia dengan Allah SWT.

At-Taqwa Centre sudah mampu menghidupi dirinya sendiri bahkan mampu memberikan kesejahteraan bagi masyarakat sekitar. Hal tersebut terbukti dari programprogram bisnis dan program sosial yang dimiliki, yaitu pertama, At-Taqwa Centre Mampu membuka peluang usaha, seperti menyiapkan kios-kios atau kantin yang diperuntukan bagi kemudahan para jamaah masjid untuk sekedar makan, minum, membeli kepentingan pribadi yang ada

\footnotetext{
${ }^{14}$ Dokumentasi, institusional profile, LAZISWA At-Taqwa Cirebon.
} 
hubungannya dengan ibadah (seperti sandal dan sabun) dan sebagainya.

At-Taqwa centre juga membuka peluang usaha dalam bentuk lain, seperti rias pengantin bagi masyarakat yang menggunakan aula untuk acara akad dan resepsi pernikahan, musik gambus ataupun grup rebana. Kedua, At-Taqwa Centre mampu memberdayakan masyarakat. Dan tiga, At-taqwa Centre mengadakan program-program pemberdayaan masyarakat baik langsung ataupun tidak langsung.

\section{HAMBATAN PRAKTIK BISNIS DAN SOSIAL MASJID AT-TAQWA CIREBON}

Berdasarkan dari hasil penelitian, terdapat beberapa hambatan dalam praktik bisnis dan sosial di masjid At-Taqwa Cirebon, yaitu pertama, Peraturan Daerah (Perda) No. 2 tahun 2015 pasal 3 ayat (6) yang berisi bahwa peruntukan alun-alun Kejaksan sebagai sarana olah raga dan upacara hari besar kenegaraan. Selain itu, alun-alun tersebut juga dilarang untuk digunakan sebagai sarana PKL dan parkiran. Oleh karena itu, hal ini dapat mengurangi pendapatan infak dari jamaah. Alaun-alun yang selama ini dapat dijadikan lahan parkir bagi jamaah, sekarang hanya dibatasi bagian bawahnya saja, sehingga mengurangi kenyamanan bagi jamaah yang berkunjung dan dapat menyebabkan berkurangnya jamaah yang ingin beribadah ke masjid Attaqwa.

Kedua, kaderisasi merupakan sarana keberlanjutan program keumatan. Oleh karena itu, ketidakmampuan kader dapat menyebabkan At-Taqwa Centre berjalan di tempat, bahkan berjalan mundur. Dari hasil penelitian, ada beberapa pengurus dan karyawan yang belum banyak mengetahui program-program yang ada di At-Taqwa Centre. Akan tetapi itu dapat diminimalisir dengan seringnya diselenggarakan acara pertemuaan, keterbukaan informasi, dan bimbingan dari para staekholder At-Taqwa Centre.
Dan ketiga, kepentingan politik dan kepentingan primodial dapat menyebabkan laju At-Taqwa Centre menjadi lambat, bahkan memporak-porandakan pondasi kokoh yang telah dibangun sebelumnya. Kemungkinan tersebut dapat dilihat dari SK Kepengurusan At-Taqwa Centre yang ditandatangani oleh Wali Kota Cirebon, yang memungkinkan adanya kontrak politik dan masuknya orang-orang politik ke dalam sistem kepengurusan At-Taqwa Centre. Akan tetapi menurut peneliti hal itu sudah diantisipasi oleh jajaran pengurus At-Taqwa Centre dengan AD/ARTnya. Diantara AD/ART yang dapat menjamin kelangsungan dan kaderisasi, yaitu syarat pemimpin At-Taqwa Centre adalah yang sudah menjadi anggota At-Taqwa Centre minimal 1 (satu) periode terakhir.

\section{KESIMPULAN}

Berdasarkan uraian di atas, dapat ditarik tiga kesimpulan, yaitu: pertama, praktik bisnis At-Taqwa Centre adalah kepanjangan dari Islamic Centre Kota Cirebon. Manajemen At-Taqwa Centre membedakan keuangan yang dihasilkan dari badan usaha yang dihasilkan dari pemanfaatan lahan yang dimiliki yang digunakan untuk akad-akad atau transaksi yang sengaja untuk mendapatkan laba/profit, dengan keuangan yang dihasilkan dari infak shadaqah dan akad-akad tabarru lainnya, meskipun dari kedua model keuangan ini nantinya dikumpulkan dan dilaporkan pada bendahara utama.

Kedua, praktik sosial At-Taqwa Centre adalah kegiatan-kegiatan atau program-program yang dilakukan yang bersifat sosial tidak mengharapkan keuntungan. Dan ketiga, dampak praktik bisnis dan sosial At-Taqwa Centre terhadap kewirausaan dan pemberdayaan masyarakat. 


\section{DAFTAR PUSTAKA}

Departemen Agama RI, Al-Qur'an dan

Terjemahnya, Jakarta: PT. Intermasa, 1986.

http://ririgusriani.blogspot.co.id/2013/06/ma najemen-pengelolaan-masjididarah.html.

Nurhasanah, Neneng. Mudharabah dalam Teori dan Praktik. Bandung: PT. Refika Aditama, 2015.

Sahroni, Oni dan Adiwarman A. Karim. Maqashid Bisnis dan Keuangan Islam Sintesis Fikih dan Ekonomi. Jakarta: PT. Raja Grafindo Persada, 2015.

Moleong, Lexy J. Metodologi Penelitian Kualitatif. Bandung: PT. Remaja Rosda Karya, 1997.

Nasution. S. Metode Penelitian Naturalistik, Kualitatif. Bandung: Tarsito, 2005.

Narbuko, Cholid dan Abu Ahmadi. Metodologi Penelitian. Jakarta: Bumi Aksara, 2007.

Emzir. Metodologi Penelitian Kualitatif: Analisis Data. Jakarta: Rajawali Press, 2012.

Sugiono. Memahami Penelitian Kualitatif. Bandung: Alfabeta, 2014.

https://id.wikipedia.org/wiki/Masjid_At-

Taqwa_Cirebon. 